\title{
LX. Account of a journey to the summit of Mont Perdue: read in the French National Institute
}

\section{Ramond}

To cite this article: C. Ramond (1804) LX. Account of a journey to the summit of Mont Perdue: read in the French National Institute, Philosophical Magazine Series 1, 19:76, 364-370, DOI: 10.1080/14786440408676580

To link to this article: http://dx.doi.org/10.1080/14786440408676580

曲 Published online: 18 May 2009.

Submit your article to this journal $\lceil\pi$

Џ Article views: 2

Q View related articles $\asymp$ 
LX. Account of a Journey to the Summit of Mont Perdu: read in the French National Institute by C. Ramond*.

I

several times attempled to ascend Mont Perdu, but was always stopped at a little distance from its summit by precipices and an accumulation of ice, which it was impossible for me to pass. I was, however, anxious to reach it, either to verify, by the help of my barometer, the elevation of this mountain, which appears to be the highest of the Pyrenees; or to ascertain the nature and disposition of the banks of which the summits are formed: and thus to place beyond all doubt one of the most singular geological phænomena ever observed.

Of all the faces of Mont Perdu there was only the eastern declivity which afforded me any chance of success. On that side there is a very high defile, which the intrepid mountaineers sometimes pass in order to proceed directly from the valley of Beousse to that of Fanlo: this is what is called the Col deNiscle. I was persuaded that by proceeding from this defile it would not bedifficult to ascend the peak itself, if the interval by which I was separated from it did not conceal from me some obstacle which it was impossible to surmount. I therefore sent two of my best guides to explore the way, and followed them myself four days after. I now found that I was not deceived in my opinion, and that I had conjectured the real route to Mont Perdu.

I took my first station at the Port de Pinede. In the Pyrenees the name of port or gate is given to those defiles which serve as passages of communication between one valley and another. The latter is in the Spanish boundaries, and is at a considerable elevation. According to a baronetrical observation, it is 2516 metres, or 1291 toises ; being 98 metres higher than that of the Col du Grand Saint Bernard. The Port de Pinede, however, is far from being the most elevated passage of this part of the Pyrenees.

Here the Col de Niscle is seen opposite; but the spectator is separated from it by the valley of Beousse. We therefore descended, proceeding in an oblique direction towards those enormous walls which sustain the lake of Mont Perdu and its terrace; and we arrived at the point where the torrent, issuing from this lake, falls down in a most awful

- From Annales du Museum Nationale d'Histoire Naturelle, No. 13. 
cataract to the bottom of the valley. Here we passed the night in the open air, surrounded by the vapour of the cascades above us; Mont Perdu suspended over our heads, an abyss below our feet, and the storm growling every where around us.

Our first labour in the morning was to ford the torrent which discharges itself from the lake: its depth, its great rapidity, and in particular the coldness of the water, rendered this operation exceedingly troublesome. The water made the thermometer rise to only two degrees above congelation.

From this place to the top of the Col de Niscle we experienced no other difficulty than that which arose from the great inclination of the declivities. I ascertained the height of this defile, and found it to be on a level with the Port de Pinede, and a little more than that of the lake.

The last stages of Mont Perdu appear to the west of this defile, and rise suddenly with an awfulness which announces the avenues to the summit. Four or five terraces piled one upon the other form so many stories, the steps of which are in part covered with eternal snow, and ruins, which in some measure facilitate the approach to these walls, otherwise inaccessible. The first of these ruins are very large blocks of gres containing testacea; among which I found fragments of calcareous schist, strongly stained with argil, and interspersed with small polypiers to which I never saw any analogous, and which seem to constitute a new genus. Higher up, the ruins become smaller; and the greater part of them belong to a calcareous kind of stone, compact, blackish, and singularly fretid. By being crushed under our feet it infected the air with a nauseous odour, which had no similarity to any of those called forth by percussion from any of the common hepatic and sulphureous stones.

We employed more than an hour in traversing these immense ruins; and this part of the journey fatigued us very much, by the efforts we were obliged to make in climbing up the steep declivities, and in consequence of the mobility of the soil, which had a tendency to throw us towards the precipice.

At length we arrived at the upper terrace, and found ourselves on a band of solid rocks. This band was at first a narrow ridge cut out like the roof of a house; but it gradually became broader, and conducted us to a kind of valley or commencement of the glaciers, with which the peak is surrounded. Here I found the last rocks which I was able 
to observe, as all the rest were covered by the ice and the snow. I here discovered a repetition of those calcareous banks interlarded with silex, which $\mathrm{I}$ saw at the Port de $\mathrm{Pi}$ nede. They affect in the like manner a situation nearly vertical, and a direction parallel to that of the chain ; they are accompanied with laminæ of another calcareous stone, very much charged with sand, and which contain so great a quantity of lenticular numismals, that they often seem to be almost entirely formed of them.

When we arrived at this terrace we were obliged to ascend the glaciers, by the lower precipices of which I had been hitherto stopped; but this time I approached them at their origin, and consequently at the place where they have the least inclination. The passage, however, was disagreeable and very dangerous: sometimes the surface was slippery, hard, and resisted our cramp irons; sometimes we sunk into the fresh snow, which had fallen on the summits towards the middle of July. Beneath this snow we felt fissures, where we were every moment in danger of being lost. Other fissures were open, and opposed our passage ; and we had very nearly been stopped by the last, at the distance of two hundred yards below the summit. This fissure extended transversally from the commencement of the glacier as far as the precipices of the valley of Beousse. We had no other resource than to clear this interval by leaping down : we did so, and succeeded: this was the last obstacle we had to encounter. I measured the visible depth of this fissure, and found it to be 50 feet; and as the point where we passed corresponded to the convexity of the mountain, it was evident that it was the place where the glacier had the least thickness.

From this place I beheld the summit, which before had been concealed from me by the disposition of the declivities which I had traversed. It appeared under the form of an obtuse cone, covered with the purest snow. The sun shone at the time in full splendour, and the sky appeared of a dark blue colour, so strongly tinged with green that my guides were struck with its strange appearance. The former shade has been observed on all high mountains, but there is no instance of the second; and I do not know to what cause this singular optical illusion is to be ascribed.

At a quarter past eleven $I$ reached the summit, and had at length the pleasure of seeing the Pyrenees at my feet. I immediately prepared my instruments for making experiments. A violent wind prevailed at east-south-east, which rendered this operation very difficult, and which occs- 
sioned some confusion in the results. At noon I noted down the heights of the barometer and thermometer. The corresponding operations were made at Tarbes: at that place, the barometer, when every correction was made, stood at 27 inches 1.47 line; and the thermometer, at $20.50^{\circ}$ of Reaumur. At the summit of the peak the barometer was 18 inches 11.14 lines; and the thermometer at $5.50^{\circ}$ above the freezing point. The height given by calculating these observations is about 72 metres, or 37 toises below what is given by trigonometrical observations; but this difference seems to have arisen from the stormy state of the atmosphere : at least I think myself authorised to infer so, from more than 600 operations of the same kind, at different heights, with a view to ascertain the nature, extent, and influence which the different modifications of the atmosphere have on measures obtained by means of the barometer.

The peak is covered with snow to its summit : this snow is continued towards the north, and transformed into an immense glacier, which descends by stories to the margin of the lake; its vertical height being about 800 metres.

On the south, however, the face of the peak is uncovered; but this is occasioned not so much by the action of heat as by its steepness : as the snow cannot adhere, it continually falls down from the top of the mountain on a slope six or seven hundred metres below, where it forms a glacier of such extent as to resist the direct and reverberated heat to which it is exposed by its situation.

The uncovered part of the mountain did not exhibit to me any strata in their natural place : it is an accumulation of ruins divided by time, macerated by the snow, buffeted by the winds, and beaten by the thunder, of which the greater part bears impressions. All these ruins belong to the calcareous kind of stones, compact and foetid, which are here in alternation with shell stones. I examined them with an attention suited to the importance given them by their situation. They contain a small quantity of fine sand, coals, a little iron, and a foetid cadaverous principle, which seems to arise from a bitumen of an animal origin.

This last conjecture is certainly well justified by the dreadful destruction of the marine animals which accompanied the formation of these mountains. This fotidity, therefore, is not exclusively annexed to the strata of marble found here. It is observed on breaking gres, of which carbonate of lime constitutes the smallest part, in the same manner as sand is found in marble, in which one might scarcely 
scarcely suspect its existence. All these masses form different mixtures of similar matters : sand, lime, fretid carbonate, argil, shells, united in all possible proportions, according to accidents which modified in every point the influence of general causes. Such are the elements of all these strata and veins arranged here in so capricious a manner, and which succeed each other with so much irregularity.

From the top of Mont Perdu the eye beholds, at one time, all this system of similar mountains: it is a long series of summits with upright strata arranged in the same line, and which divide the immense horizon of the spectator into two parts, as different in level as distinct by the form of the mountains with which they are filled.

On the north, primitive mountains arise, the sharp and torn summits of which are closely enchained, and form a large band, the elevation of which totally intercepts a view of the plains of France.

On the south the spectacle is very different; every thing is suddenly depressed. It is a precipice of from a thousand to eleven hundred metres, the bottom of which is the sum. mit of the highest mountains of that part of Spain. None of the summits have 2500 metres of absolute elevation, and they soon degenerate into low round hills, beyond which opens an immense prospect of the plains of Arragon.

But what attracted my attention was the aspect of that southern band of the Pyrenees, on which I looked down as if from the clouds. It seemed to me to be divided into two distinct parts. The nearest to the plains exhibited to my view those long ridges and those hollaw valleys which in general form the calcareous hills on the borders of the large chains. On the other hand, the band which adheres to Mont Perdu, and which serves it as a base, retained that strange appearance which distinguishes every thing that betongs to this singular mountain. It is an immense and long plateau, the whole surface of which, seen from this height, appears to be nearly on a level. Some paps only, and a few small hills, separated by broad but shallow valleys, appear on it. But in the midst of these superficial inequalities, traced out by antient currents, there are four enormous crevices with sides exactly vertical. They proceed diverging from the bases of the peak, and are continued to the limits of the plateau, the protuberances and valleys of which they divide, and they even intersect it itself to its foundations. They absorb also the waters of it, and conceal them by thick forests observed in their hollows. These fissures, which 
which might be supposed recently formed, have preserved so well their salient and re-entering angles, that every thing perfectly corresponds on both sides-their sinuosities and undulations - so that one might think their edges, in order to unite, waited only for a new effort of the power which disjoined them.

One might traverse these crevices without any advantage, were they not seen from above. Their extent, their depth, and the gigantic size of all their proportions, would not allow one to conjecture their origin and nature. To approach them, one must seek for the opening in the Val de Broto or of Fanlo. They are vast and majestic valleys covered with forests as old as the world, and which are known only to some shepherds who conduct thither their migratory flocks.

I spent two days in that called Val d'Ordera. I never saw any thing more striking or extraordinary. The soil is a series of terraces, perfectly horizontal, formed by banks of gres, between which is observed red gres, considered by geologists as one of the oldest on the globe. The torrent falls in cascades so regular, that the long ramp down which it pours seems to have been formed by the art of man. Or the other hand rise, as far as the eye can reach, the sides of this vast fissure disposed in stories of a prodigious height, and of which the steepness, the matter, the colour and joinings excite so much the idea of human structures, that the spectator thinks he sees an immense edifice in ruins. From the bottom of this fissure I ascended to the plateau. Its elevation is 2430 metres or 1200 toises above the level of the sea, and the depth of the fissure is 900 metres or 460 toises towards its middle, and 1257 metres or 645 toises towards its mouth.

Every thing is secondary in these enormous masses. Pudding stones, gres, calcareous and fotid shell-stones, are the materials; and among the marine bodies inclosed in them the most predominant genus is that of the numismals, which are found every where in such prodigious abundance, that it strikes with awe the mind the best accustomed to the idea of the grand devastations of nature.

In regard to the plateau itself, it is a frightful desert. Being too high to produce trees, it stifles the small vegetation which exists by the mobility of the ruins with which it is covered, and scarcely are there seen here and there a few meagre grass-plats. The heights even of Mont Perdu are not so naked : as far as the last stories $I$ found rare and superb plants; and I collected, at the distance of some metres below the summit, the cerastium alpinum and the aretia 
areiia alpina in full bloom. I never saw the latter so vigorous and so beautiful as I did at an elevation which is the greatest, perhaps, at which parasitic plants have been observed in the same latitude.

These organic beings were the last I met with on the summit of Mont Perdu. I remained on it two hours; and to whatever distance I turned my eyes I observed no living creature but an eagle which passed over us, flying directly against the wind with inconceivable rapidity : in less than a minute we lost sight of it.

We struggled against this impetuous wind, over which an eagle triumphed so easily, and which made us experience a considerable degree of cold. No wind diminishes so speedily the sensible heat as the south wind, when one is exposed to its action in the superior regions of the atmosphere: it derives this property from its dryness and rapidity, which promote and hasten the evaporation of which bodies are susceptible. We were penetrated by it, though the thermometer indicated a very low temperature. This is the only inconvenience I experienced. We could breathe without difficulty this air so light, and which is not sufficient for the respiration of many others. I have more than once seen vigorous persons obliged to stop at a less height. On the Col du Geant, where the air was not so highly rarefied, Saussure experienced a shortness of breath and uneasiness as soon as he made the least exertion. Here nothing similar occurred; the state of the pulse only indicated $\mathbf{a}$ change independent of the agitation of the journey : it was not calmed by rest. During the whole time that we continued on the summit it remained small, tense, and accelerated in the ratio of 5 to 4 . This fever, which is nerrqus, announced the uneasiness we should have experienced at a greater height; but, according to what we experienced, it was attended with an effect contrary to what a degree more would have produced. Far from occasioning dejection, it seemed to support my strength and to rouse my spirits. I am persuaded that we were often indebted to it for that agility of the limbs, delicacy of sensation, and tlights of fancy, which instantly dissipated our fatigue and apprehension of danger; and we ought not, perhaps, to seek any where else for the secret cause of that enthusiasm found in the accounts of all those who have ascended to extraordinary heights. 